\title{
MOLECULAR DIAGNOSIS AND EVOLUTIONARY RELATIONSHIP ANALYSIS OF PLANT PARASITIC TEA GARDEN NEMATODES FROM DIFFERENT TEA ESTATES IN SYLHET REGION OF BANGLADESH
}

\author{
MAB Siddique ${ }^{1}$, TA Asa ${ }^{1}$, MMH Sohag $^{2}$, MSH Chowdhury ${ }^{3}$, Iqbal ${ }^{1}$ and $\mathrm{K}$ Islam ${ }^{1^{*}}$ \\ ${ }^{1}$ Department of Genetic Engineering and Biotechnology, Shahjalal University of Science and Technology, \\ Sylhet-3114, Bangladesh \\ ${ }^{2}$ Department of Genetic Engineering and Biotechnology, Jagannath University, Dhaka-1100, Bangladesh \\ ${ }^{3}$ Department of Chemistry, Shahjalal University of Science and Technology, Sylhet-3114, Bangladesh
}

\begin{abstract}
Nematodes from plant-parasitic sources are ever-present and incidental to plant growth as well as crop production. The damage of tea gardens caused by nematode is often non-specific and easily confused with symptoms. The present study determined the parasitic and non-parasitic nematodes population in different tea gardens of the Sylhet region by their morphological and partial molecular characterization. Out of 13 tea gardens, it was observed that BTRI, Karimpur, Mathiura, and Tarapur tea garden has the highest number of parasitic and non-parasitic nematodes. After PCR amplification, DNA bands with desired amplicon size were detected by gel electrophoresis. Among thirteen soil samples, nematodes from Malnichara, Karimpur, BTRI, Mathiura , and Finlay had partially confirmed the presence of rootknot nematode (Meloidogyne spp.), root-lesion nematode (Pratylenchus brachyurus), burrowing nematode (Radopholus similis), reniform nematode (Rotylenchulus reniformis) and lance nematode (Hoplolaimus columbus) consequently based on approximately base pair of 1.7, 1.1 and $0.52 \mathrm{~kb}$ (different Meloidogyne spp.) $0.52,0.52,0.25$ and $2.3 \mathrm{~kb}$ of specific genes. From evolutionary analysis, it might be said that Meloidogyne species are strongly related with each other making clusters except Meloidogyne natalie where this one is closely related with Hoplolaimus columbus in their evolutionary relationship as remaining others (Rotylenchulus reniformis, Radopholus similis, Pratylenchus brachyurus) are in different clusters in the same clade and this result could be confirmed after sequencing.
\end{abstract}

Key words: Evolutionary relationship, Molecular diagnosis, Plant parasitic nematode, Tea garden

\section{Introduction}

Tea, Camellia sinensis, is a principal perennial cash crop in Bangladesh that has a great impact on agricultural export and domestic demand for sustaining the economy of Bangladesh. Tea is a popular nonalcoholic drink made from the leaves of an evergreen shrub or tree of Camellia sinensis belonging to the family Theaceae over the world. Tea is cultivated as a monoculture over large adjacent areas during the last 165 years and generated a strong tea ecosystem for various insects, mites, and nematodes in Bangladesh. Sylhet, Chittagong, and Phanchagarh district is the main ecological zone for the cultivation of tea in Bangladesh. The spreading and persistency of these insects, mites, and nematodes are responsible for the performance of shade trees, ancillary crops forests, a uniformity of cultural practices such as sequential pruning cycles, weekly plucking rounds, weeding, mulching, and so on. Above 40 species, nearness 20

*Author for correspondence: kamrul-gen@sust.edu 
genera of pest of nematode have been identified in different tea gardens across the world (Mamun 2011). In the tea cultivation area in Bangladesh, 71 insects, mite, and nematode species belonging to 45 families under 14 orders are recorded as pests of tea, and among them, $25.35 \%$ of species are foliar insects and mites, $26.76 \%$ are soil insects and nematodes, $21.13 \%$ are beneficial insects and $26.76 \%$ are butterflies. Different plant parts of tea such as leaf, root, stem, flower, and seed are affected by these pests of insects, mites, and nematodes that results a loss of production about 15\% every year (Azad et al. 2020). Soil nematodes are tiny $(0.3-5.0 \mathrm{~mm}$ ) worm-like animals that are plethoric and numerous in all told soils (Yeates and Bongers 1999). They play a crucial role in the decomposition of organic matter and nutrient cycling. One of the foremost goals of property agriculture ought to be to boost populations of free-living nematodes and scale back that of plant-parasitic nematodes.

Diagnosis of plant-parasitic nematodes associated with tea garden issues is difficult as a result of symptoms varying with the environmental conditions and the plant growth stage. Owing to the wide array of disorders that would be caused by nematodes, an associate degree assay of soil and root for nematodes is important. Some symptoms like root-knot, discoloration of tea bushes, and root lesion are appeared with poignant of various species of the nematode as early recognized (Kamunya et al. 2008). In our country, most of the tea garden uses pesticides for controlling pest for better leaf production. Farmers do not perform accurate diagnosis in many cases during the control procedure for tea pests. Accurate identification of individual species as well as characterization of pathogenicity of tea garden plant-parasitic nematodes are regarded as indispensable tasks for designing effective diagnosis, treatment and management strategies of nematode infections or probable causes of host-plant resistance against plant-parasitic nematodes associated with tea plants (Yeates et al. 2015).

In modern nematode taxonomy, molecular systematics is a very important tool (Subbotin 2005 \& 2006, Ye et al. 2007). For a further appropriate understanding of agricultural pest biology, evolutionary relationship studies among nematode species are very imperative, though it is not essential for nematode taxonomy (Subbotin 2001). For evolutionary analysis of plant-parasitic nematodes, different genomic regions viz. 18S rDNA, ITS, and 28S rDNA, as well as mtDNA are used most frequently (Subbotin 2005 \& 2006, Ye et al. 2007, Kumari 2012). 18 S and ITS regions are very common among molecular systematics for near-fulllength sequences and evolutionary analysis of many plant-parasitic nematodes (Blaxter et al. 1991, Subbotin 2006).

Unfortunately, little research has been done on this purpose, and intensive studies are required to expand and sustain tea production. Therefore, proper identification of beneficial and plant-parasitic nematodes associated with the tea soils is important. This study focused on the molecular identification of plant-parasitic nematodes, collected from several tea gardens in the Sylhet region of Bangladesh. Besides this, we have investigated the evolutionary relationships among the identified plant-parasitic nematode species from the available database.

\section{Materials and Methods}

\section{Collection of nematode sample and population determination}

Tea plant-parasitic nematode containing soil has been collected from different tea gardens of the greater Sylhet region. Considering the depth of $0-20 \mathrm{~cm}$ and $20-40 \mathrm{~cm}$, soil samples were collected by using a soil auger. Rhizosphere soil samples were collected from stressed tea bushes. The stressed tea bushes were considered as those that did not have two leaves and a bud, become yellowish, wilting and, stunted growth (Adegbite and Adesiyan 2006). The soil was taken in proper air circulated plastic bag and transported in an insulated box to the laboratory and stored at $4^{\circ} \mathrm{C}$ until processing on the same day. 
For the nematode extraction from the soil, a modified Baermann funnel method (Cesarz et al. 2019) was used which is easy to isolate the nematodes. In the modified Baermann funnel, the apparatus consists of a plastic box with a mass in it. Two tissue papers (crisscross manner) were placed there. Each soil sample was mixed thoroughly, and $200 \mathrm{~g}$ of soil was subsampled and was placed over the tissue with distilled water by cover-up and kept still overnight, where nematodes were moved through the tissue and settled at bottom of the box by gravity. The next morning the nematode suspension was collected and identified according to their typical morphological features, considering the presence of Sylhet. The population density was estimated by the formula (number of nematode/ml of suspension) $\times$ (total volume of the nematode suspension from $200 \mathrm{~g}$ of soil). The counting was done on a nematode counting slide under a dissecting microscope.

\section{DNA extraction}

DNA extraction was done using the standard protocol of Clear ${ }^{\circledR}$ Detections Nematode DNA extraction and purification kit (Product no: EX-N-P-NDEP, Netherlands) which is designed to extract and purify DNA from nematode suspensions and/or multiple cysts. The kit separates DNA from proteins, detergents, and low molecular weight compounds. The purified nematode DNA was used for downstream applications such as PCR.

\section{PCR amplification using nematode specific primers}

In the present study, 16s rRNA regions from extracted and purified DNA regions were amplified by different nematode-specific primers (Table 1). For the amplification process, PCR mixture has been prepared with an aliquot of $50 \mu \mathrm{l}$ solution, where $25 \mu \mathrm{l}$ was the master mixture, $4 \mu \mathrm{l}$ each for forward and reverse primer, $8 \mu \mathrm{L}$ for template, and the remaining are nuclease-free water. All reactions are performed according to the following conditions: initial denaturation has been done for 1 minute with $94^{\circ} \mathrm{C}$, then the cycling conditions for the amplification step has been done for 35 cycles and the extension period is for 1 minute at $72^{\circ} \mathrm{C}$. Then the preparation was kept for 7 minutes for the final extension and then storage has been done at $4^{\circ} \mathrm{C}$. All PCR amplifications were run on the Thermal Cycler (SimpliAmp ${ }^{\text {TM }}$ Thermal Cycler, Applied Biosystem ${ }^{\circledR}$, and the USA).

Table 1. List of primers for PCR amplification

\begin{tabular}{|c|c|c|c|c|c|}
\hline Nematode & $\begin{array}{l}\text { Scientific } \\
\text { name }\end{array}$ & Primers & Primer sequence & $\begin{array}{l}\text { Amplicon } \\
\text { size (bp) }\end{array}$ & Ref. \\
\hline \multirow{2}{*}{$\begin{array}{l}\text { Burrowing } \\
\text { nematode }\end{array}$} & \multirow{2}{*}{$\begin{array}{l}\text { Radopholus } \\
\text { similis }\end{array}$} & RS_F & 5'CTA CAA ATG TGA CGC GAA -3' & \multirow[t]{2}{*}{518} & \multirow{2}{*}{$\begin{array}{l}\text { Liu et al } \\
\text { (2011) }\end{array}$} \\
\hline & & RS_R & 5'CAA TCT GCA CAA TGA ACA TAC - $3^{\prime}$ & & \\
\hline \multirow{2}{*}{$\begin{array}{l}\text { Reniform } \\
\text { nematode }\end{array}$} & \multirow{2}{*}{$\begin{array}{l}\text { Rotylenchulus } \\
\text { reniformis }\end{array}$} & RR_Ren240_F & 5'-ACC GGC TTA ATT GCA ATG GT-3' & \multirow[t]{2}{*}{246} & \multirow{2}{*}{$\begin{array}{l}\text { Sayler e } \\
\text { al. (2012) }\end{array}$} \\
\hline & & $\begin{array}{l}\text { RR_Ren240_ } \\
\text { R }\end{array}$ & 5'-ACA ACT GCT CAA CAA CGC AG -3' & & \\
\hline \multirow{2}{*}{$\begin{array}{l}\text { Root-knot } \\
\text { nematode }\end{array}$} & Meloidogyne & $\mathrm{C} 2 \mathrm{~F} 3$ & $5^{\prime}$-GGT CAA TGT TCA GAA ATT TGT GG - $3^{\prime}$ & \multirow[t]{2}{*}{528} & \\
\hline & spp. & 1108 & $5^{\prime}$-TAC CTT TGA CCA ATC ACG CT -3' & & $\begin{array}{l}\& \text { Harris } \\
(1993)\end{array}$ \\
\hline \multirow{2}{*}{$\begin{array}{l}\text { Root-lesion } \\
\text { nematode }\end{array}$} & \multirow{2}{*}{$\begin{array}{l}\text { Pratylenchus } \\
\text { brachyurus }\end{array}$} & PB_18S & 5'-TTG ATT ACG TCC CTG CCC TTT-3' & \multirow[t]{2}{*}{518} & \multirow{2}{*}{$\begin{array}{l}\text { Machado } \\
\text { et al } \\
(2007)\end{array}$} \\
\hline & & PB_RN58SR & 5'-ACG AGC CGA GTG ATC CAC CG -3' & & \\
\hline \multirow{2}{*}{$\begin{array}{l}\text { Lance } \\
\text { nematode }\end{array}$} & \multirow{2}{*}{$\begin{array}{l}\text { Hoplolaimus } \\
\text { columbus }\end{array}$} & Hoc-1F & 5' - AAC CTG CTG CTG GAT CAT TA - $3^{\prime}$ & \multirow[t]{2}{*}{581} & \multirow{2}{*}{$\begin{array}{l}\text { Bae \& } \\
\text { Szalanski } \\
\text { (2009) }\end{array}$} \\
\hline & & $\mathrm{HC}-1 \mathrm{R}$ & $5^{\prime}$-TCA GCA CAC AAT GGT ACC TTT-3' & & \\
\hline
\end{tabular}




\section{Sequence retrieval}

For in silico observation of the expected nematodes species (among them eight sequences were from Meloidogyne spp.) nucleotide sequences were retrieved from NCBI (https://www. ncbi. nIm. nih. gov/ nucleotide). The sequences were saved into fasta format and were processed through Molecular Evolutionary Genetic Analysis (MEGAX) tools for the evolutionary analysis among the twelve nematodes species.

\section{Construction of evolutionary relationship}

An evolutionary relationship among the twelve species was determined on the comparison of the Polymerase Chain Reaction amplified result of that relevant species. Here, the evolutionary analysis was prepared with the Neighbor-Joining method with a bootstrap replicate value of 1000 .

\section{Results and Discussion}

\section{Measurement of population densities}

Based on morphological characteristics of nematodes isolated from soil samples, plant-parasitic nematodes were identified in 9 of 13 soil samples from different tea gardens, with densities ranging from 50 to 200 individuals per $5 \mathrm{ml}$ of nematode solution extracted from $200 \mathrm{~g}$ of soil (Table 2). In the present study, it was found that Karimpur (sec.1) and Finley tea estate among all of the collected samples showed the highest number of parasitic nematodes.

Table 2. Sampling and population densities of plant parasitic tea garden nematodes

\begin{tabular}{clccc}
\hline $\begin{array}{c}\text { Sample } \\
\text { No. }\end{array}$ & \multicolumn{1}{c}{$\begin{array}{c}\text { Name } \\
\text { of tea garden and Location }\end{array}$} & $\begin{array}{c}\text { Nematode } \\
\text { with Sylhet } \\
\text { in } 1 \text { drop }\end{array}$ & $\begin{array}{c}\text { Total number of } \\
\text { nematodes in } \\
5 \mathrm{ml}\end{array}$ & $\begin{array}{c}\text { Total number of } \\
\text { Parasitic nematode } \\
(\%)\end{array}$ \\
\hline 1. & Karimpur Tea Estate (sec.1), Moulavibazar & 2 & 100 & 100 \\
2. & Karimpur Tea Estate (sec.2), Moulavibazar & 0 & 50 & 0.0 \\
3. & Karimpur Tea Estate (Nursury), Moulavibazar & 1 & 100 & 50.0 \\
4. & BTRI, Srimongol & 2 & 150 & 66.7 \\
5. & BTRI Nursery, Srimongol & 0 & 50 & 0.0 \\
6. & Rajnagar Tea Estate, Srimongol & 1 & 150 & 33.3 \\
7. & Mathiura Tea Estate, Srimongol & 1 & 200 & 25.0 \\
8. & Mazdehee Tea Eastate, Srimongol & 0 & 50 & 0.0 \\
9. & Finlay Tea Estate, Srimongol & 2 & 100 & 100 \\
10. & Malnichora Tea Estate, Sylhet Sadar & 1 & 100 & 50.0 \\
11. & Lakkatura Tea Estate, Sylhet Sadar & 0 & 100 & 0.0 \\
12. & Tarapur Tea Estate, Sylhet Sadar & 2 & 200 & 50.0 \\
13. & FET Tea Garden, SUST, Sylhet Sadar & 0 & 50 & 0.0 \\
\hline
\end{tabular}




\section{Molecular detection by polymerase chain reaction}

In the present study, 13 samples were collected from different tea gardens in several locations. Here, $1 \mathrm{~kb}$ ladder was used. PCR amplification was done with nematode-specific primers yielding an amplification product of approximately 518 bps of the targeted 16S rRNA gene. Among the soil samples, nematodes extracted from the Malnichora tea garden (M2) showed 1.7, 1.1, and 0.52kb amplification of the 16S rRNA gene (Fig. 1). It is partially confirmed that M2 samples had root-knot nematodes (Meloidogyne spp.) according to their amplification sizes of 16S rRNA gene. Nematodes extracted from above mentioned six soil samples displayed 0.52, 0.52, 0.25 and $2.3 \mathrm{~kb}$ amplification of primer-specific gene (Fig. 2 and 3). It is also partially confirmed that $\mathrm{P} 2, \mathrm{X} 5, \mathrm{R} 2$ and $\mathrm{H} 3$ samples had consequently of root-Lesion nematode (Pratylenchus brachyurus) from Karimpur section 1, Burrowing nematode (Radopholus similis) from BTRI, Reniform nematode (Rotylenchulus reniformis) from Mathiura, and Lance nematode (Hoplolaimus Columbus) from Finlay tea garden respectively.

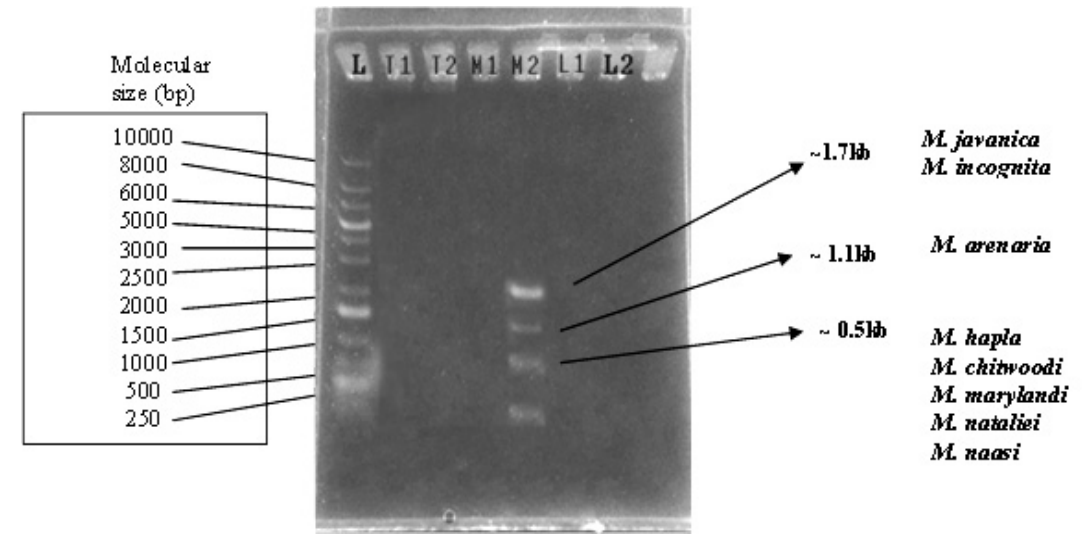

Fig. 1. Agarose gel electrophoresis of PCR products obtained from the genomic DNA of the nematodes isolates M2 for root-knot nematode (Meloidogyne spp.) from the Malnichora tea garden. $L$ on the left indicates the DNA ladder; T1 and T2 indicates the two different locations of the Tarapur Tea Estate, Sylhet Sadar, M1 and M2 indicates the two different locations of the Malnichara tea garden where L1 and L2 indicates the two sample sites of the Lakkatura Tea gardens.

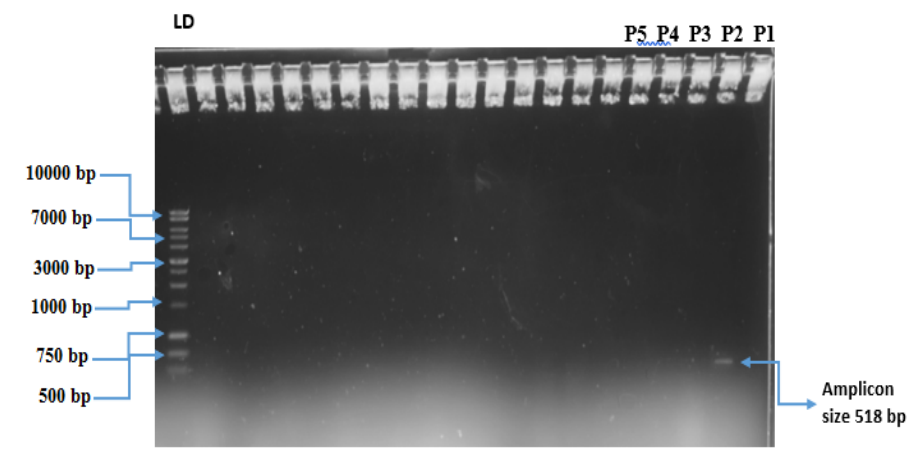

Fig. 2. $P C R$ products of the genomic DNA of the nematodes isolate from different location samples of Karimpur Tea Garden (P1, P2, P3, P4, and P5) in agarose gel. Here, we found the distinct result for the second location which is denoted as P2 in the gel. Here, LD denotes the DNA ladder. 


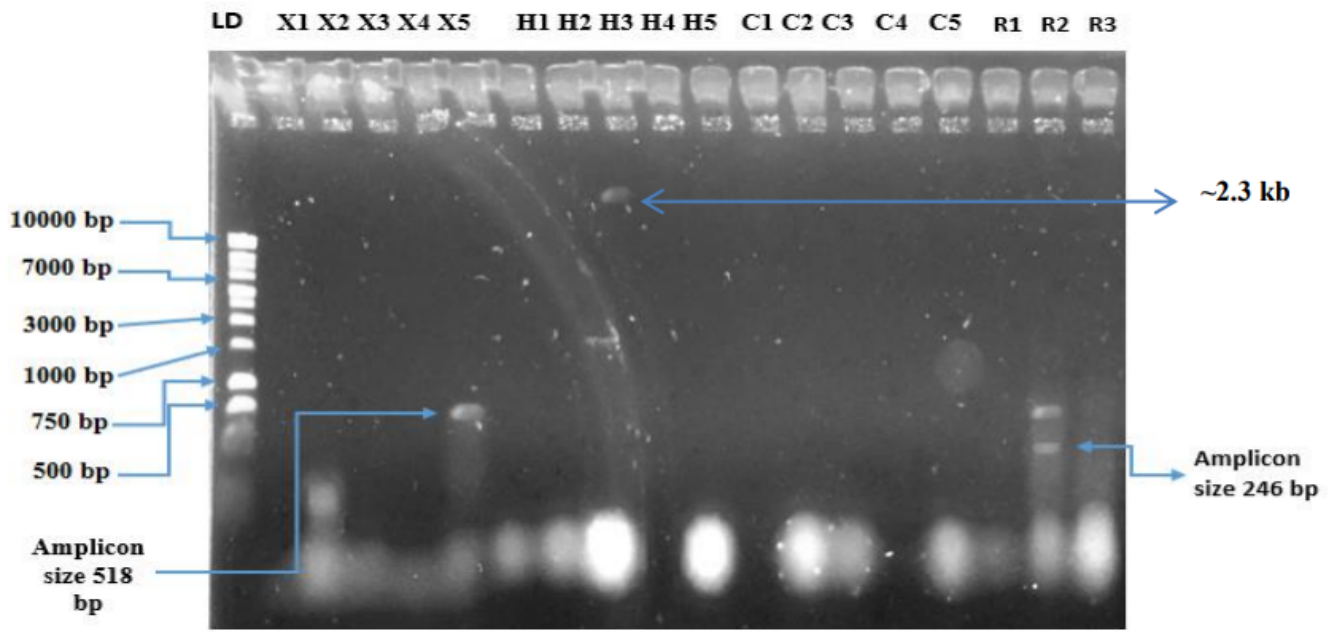

Fig. 3. $P C R$ products of the genomic DNA of the nematodes isolate from different location samples. $X$ is denoted for the samples from the BTRI where samples 1 to samples 5 are representing different locations of the same site. $\mathrm{H}$ is for the Finlay Tea Garden and five samples are labeled as 1 to 5 respectively. $\mathrm{C}$ is dedicated for the sample collected from the Rajnagar Tea Garden and five samples are numbered from 1 to 5 respectively for the different locations and $\mathrm{R}$ is reserved for the Mathiura Tea Garden. Here distinct bands are seen for X5, H3 and R2.

The present study performs extraction of DNA from nematodes sample. There has no record of extracting and molecular identification techniques for tea parasitic nematodes according to BTRI. An expeditious species identification technique for Meloidogyne spp has been represented. The benefits of the method are that it needs no radioactive isotopes and solely straightforward nematode lysis before PCR, rather than complicated extraction of DNA. The ability to identify soil nematodes permits species determinations to be conducted before planting. The specificity of the assay may allow monitoring species shifts in mixed Meloidogyne populations with single PCR amplification (Subbotin 2001). A survey of a lot of isolates ought to be conducted to verify the presence of all that necessary Meloidogyne spp. The repetition units are placed during a different region of the mitochondrial genome than the amplified region delineated within the present study.

\section{Evolutionary relationship among nematodes from different tea garden}

Nucleotide sequences of twelve nematodes species and their accession number is listed in Table 3. 
Table 3. List of identified nematode species with their accession number

\begin{tabular}{ccc}
\hline Sl. No. & Name of the nematode species & Accession number \\
\hline 1 & Meloidogyne javanica & AF387095.1 \\
2 & Meloidogyne hapla & AY268108.1 \\
3 & Meloidogyne incognita & LC030364.1 \\
4 & Meloidogyne arenaria & LC030356.1 \\
5 & Meloidogyne marylandi & JN157858.1 \\
6 & Meloidogyne chitwoodi & JN157868.1 \\
7 & Meloidogyne naasi & AY302249.1 \\
8 & Meloidogyne nataliei & MG821328.1 \\
9 & Pratylenchus brachyurus & MN578149.1 \\
10 & Rotylenchulus reniformis & KR153037.1 \\
11 & Radopholus similis & GQ281468.1 \\
12 & Hoplolaimus columbus & FJ485615.1 \\
\hline
\end{tabular}

These sequences were analysed by MEGAX tools to see the evolutionary relationship were observed among these species. The Neighbor-Joining method was applied to infer the evolutionary history of the nematode species (Saitou and Nei 1985). The replicates (1000) were used to construct the bootstrap consensus tree (Felsenstein 1985) which was further employed to represent the evolutionary history of the taxa analyzed (Felsenstein 1985).

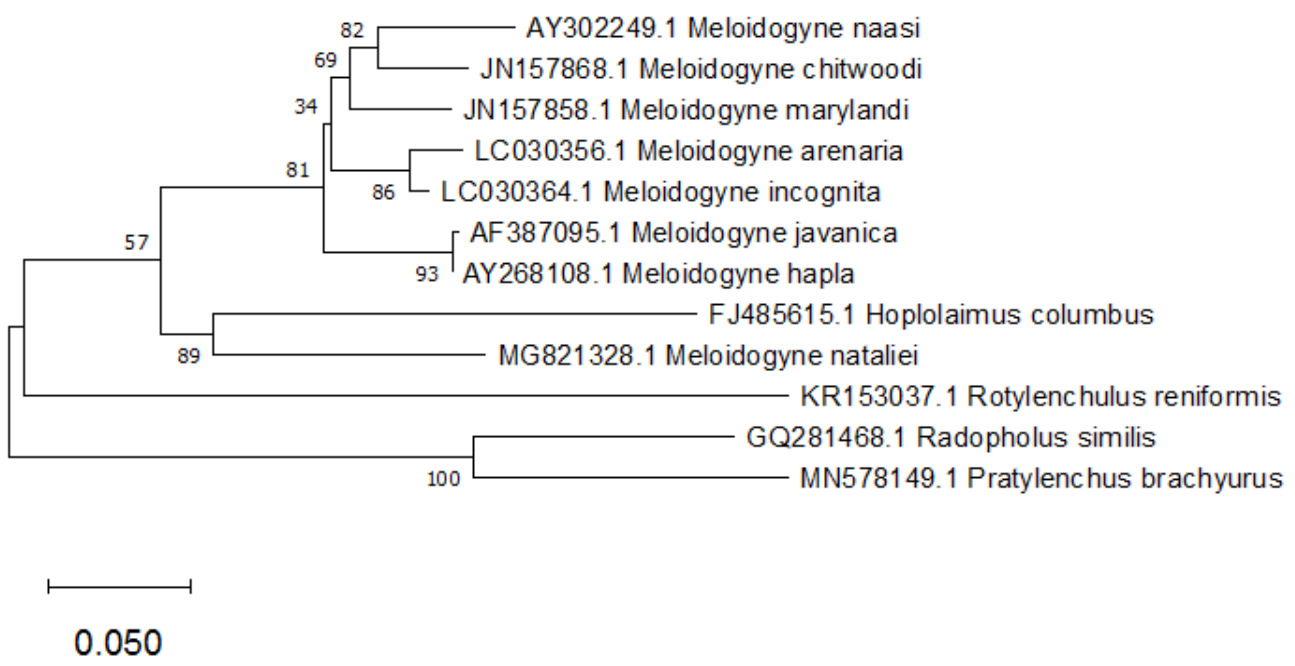

Fig. 4. Evolutionary relationship of the identified nematodes species. 
Branches corresponding to partitions reproduced in less than $50 \%$ bootstrap replicates are collapsed. The proportion (percentage) of replicate trees in the constructed bootstrap (1000 replicate) where the closely related taxa clustered together are represented alongside the branches (Felsenstein 1985). The p-distance method which is based o the proportion of nucleotide differences per site was employed to calculate evolutionary distances (Nei and Kumar 2000). This evolutionary study involved 12 nucleotide sequences. For each pair of studied sequences, all ambiguous positions were eliminated by applying the pairwise deletion option. Finally, there were a total of 1263 positions for further analysis. Evolutionary studies were performed using MEGA X (Kumar 2018). Here, Meloidogyne species are strongly related to each other making clusters except Meloidogyne natalie in a clade. This Meloidogyne natalie is closely related with Hoplolaimus columbus in their evolutionary relation where the remaining three nematodes (Rotylenchulus reniformis, Radopholus similis, Pratylenchus brachyurus) are in different clusters in the same clade evolved from the common ancestor (Fig. 4).

\section{Conclusion}

Molecular diagnosis is important for the confirmation of plant-parasitic nematode species identification and analysis of their phylogenetic relationships with available sequences in databases. The present study provides the basic information on molecular identification based on PCR band of genomic DNA and a comprehensive framework of evolutionary relationships of plant-parasitic nematodes associated with tea garden. After DNA sequencing, it will be identified to species level and this study will aid in further characterization of diverse plant-parasitic nematodes in different tea gardens in the future.

\section{Acknowledgements}

The authors would like to thank the Department of Genetic Engineering and Biotechnology, Shahjalal University of Science and Technology, Sylhet, Bangladesh for supporting technical assistance. The research work was carried out by the financial assistance of SUST Research Center (LS-17/07), Shahjalal University of Science and Technology, Sylhet, and Ministry of Science and Technology (39.00.0000.09.14.004.2019/BS-107/118), Govt. of the People's Republic of Bangladesh.

\section{References}

Adegbite A and Adesiyan S (2006). Root extracts of plants to control root-knot nematode on edible soybean. J Veg Sci., 12(2): 5-12.

Azad M, Ahmad I and Mainuddin A (2020). Application of plant extracts for pest management in tea: a study on tea leaf's thrips, Scirtothrips bispinosus. J Bio Sci., 28: 87-93.

Bae CH, Szalanski AL and Robbins RT (2009). Phylogenetic Analysis of the Hoplolaiminae Inferred from Combined D2 and D3 Expansion Segments of 28S rDNA. J Nematol. 41(1): 28-34.

Blaxter ML, De Ley P, Garey JR, Liu LX, Scheldeman P, Vierstraete A, Vanfleteren J R, Mackey LY, Dorris M, Frisse L M, Vida JT, and Thomas WK (1998). A molecular evolutionary framework for the phylum Nematoda. Nature, 392: $71-75$.

Cesarz S, Eva Schulz A, Beugnon R and Eisenhauer N (2019). Testing soil nematode extraction efficiency using different variations of the Baermann-funnel method. Soil organisms, 91(2): 61-72.

Felsenstein J (1985). Confidence limits on phylogenies: An approach using the bootstrap. Evolution 39: 783-791.

Kamunya SM, Wachira FN, Lang'at J, Otieno W and Sudoi V (2008). Integrated management of root knot nematode (Meloidogyne spp.) in tea (Camellia sinensis) in Kenya. Int J Pest Management, 54(2): 129-36. 
Kanzaki N and Giblin-Davis RM (2014). Phylogenetic status and morphological characters of Rhabditolaimus anoplophorae (Rhabditida: Diplogastridae). J Nematol. 46: 44-49.

Kumar S, Stecher G, Li M, Knyaz C and Tamura K (2018). MEGA X: Molecular evolutionary genetics analysis across computing platforms. Mol Biol and Evol. 35: 1547-1549.

Kumari S and Subbotin SA (2012). Molecular characterization and diagnostics of stubby root and virus vector nematodes of the family Trichodoridae (Nematoda: Triplonchida) using ribosomal RNA genes. Plant Pathol., 61: 1021-1031.

Liu GK, Chen J, Xiao S, Zhang SS and Pan DM (2011). Development of species-specific PCR primers and sensitive detection of the Tylenchulus semipenetrans in China. Agric Sci. China, 10: 252-258.

Machado ACZ, Ferraz LCCB and Oliveira CMG (2007). Development of species-specific reverse primer for the molecular diagnostic of Pratylenchus brachyurus. Nematropica, 37: 249-257.

Mamun M (2011). Development of tea science and tea industry in Bangladesh and advances of plant extracts in tea pest management. Int J Sustain Agril Tech., 7(5): 40-46.

Nei M and Kumar S (2000). Molecular Evolution and Phylogenetics. Oxford University Press, New York.

Powers TO and Harris TS (1993). A polymerase chain reaction method for identification of five major Meloidogyne species. J. Nematol., 25: 1-6.

Saitou N and Nei M (1987). The neighbor-joining method: A new method for reconstructing phylogenetic trees. Mol Biol and Evol., 4: 406-425.

Sayler RJ, Walker C, Goggin F, Agudelo P and Kirkpatrick T (2012). Conventional PCR detection and real-time PCR quantification of reniform nematodes. Plant Dis., 96: 1757- 1762.

Subbotin SA, Sturhan D, Chizhov VN, Vovlas N and Baldwin JG (2006). Phylogeny analysis of Tylenchida Throne, 1949 as inferred from D2 and D3 expansion fragments of the 28S rRNA gene sequences. Nematol. 8: 455-474.

Subbotin SA, Vierstraete A De Ley P, Rowe J, Waeyenberge L, Moens M and Vanfleteren JR (2001). Phylogenetic relationships within the cyst-forming nematodes (Nematoda, Heteroderidae) based on analysis of sequences from he ITS region of ribosomal DVA. Mol Phyl and Evol., 21: 1-16.

Subbotin SA, Vovlas N, Crozzoli R, Sturhan D, Lamberti F, Moens M and Baldwin JG (2005). Phylogeny of Criconematina Siddiqi, 1980 (Nematoda:Tylenchida) based on morphology and D2-D3 expansion segments of the 28S-rRNA gene sequences with application of a secondary srtucture model. Nematol. 7: 927-944.

Ye W, Giblin-Davis RM, Braasch H, Morris K and Thomas WK (2007). Phylogenetic relationships among Bursaphelenchus species (Nematoda:Parasitaphelenchidae) inferrred from nuclear ribosomal and mitochondrial DNA sequence data. Mol Phyl and Evol., 43: 1185-1197.

Yeates GW and Bongers T (2015). Nematode diversity in agroecosystems. Invertebrate Biodiversity as Zeng Y, W Ye, J Kerns, L Tredway, S Martin, M Martin. Molecular characterization and phylogenetic relationship of plant parasitic nematodes associated with turfgrasses in North Caroloina and South Carolina, United States. Plant Diseases 99(7): 982-993.

Yeates GW and Bongers T (1999). Nematode diversity in agroecosystems. Invertebrate Biodiversity as Bioindicators of Sustainable Landscapes, Elsevier, pp. 113-35. 